\title{
PENGGUNAAN FORMALIN DAN BORAKS SERTA KONTAMINASI BAKTERI PADA OTAK-OTAK
}

\author{
Harsojo dan Kadir I. \\ Pusat Aplikasi Isotop dan Radiasi, Batan, Jakarta \\ e-mail:apu.harsojo@yahoo.com
}

Diterima 18 April 2012, diterima dalam bentuk perbaikan 29 Mei 2012, disetujui 8 Juni 2012

\begin{abstract}
ABSTRAK
PENGGUNAAN FORMALIN DAN BORAKS SERTA KONTAMINASI BAKTERI PADA OTAK-OTAK. Telah dilakukan penelitian mengenai penggunaan formalin dan boraks serta kontaminasi awal bakteri pada otak-otak yang dibungkus dan tanpa pembungkus. Otak-otak tersebut diiradiasi dengan dosis 0 dan 3 kGy di IRPASENA dengan laju dosis 1,149 kGy/jam, kemudian disimpan pada 2 macam suhu penyimpanan yaitu suhu kamar dan suhu lemari es selama 4 minggu dengan interval waktu pengamatan untuk kontaminasi bakteri dilakukan setiap minggu. Hasil penelitian menunjukkan semua contoh otak-otak yang diteliti menggunakan formalin tetapi tidak menggunakan boraks. Kontaminasi awal total bakteri aerob pada otak-otak yang tanpa pembungkus dan dibungkus kemudian disimpan pada suhu kamar dengan dosis $0 \mathrm{kGy}$ terlihat pada awal minggu jumlah bakteri aerob masing-masing adalah 4,3 × $10^{7}$ dan 2,0 x $10^{7} \mathrm{cfu} / \mathrm{g}$. Setelah diradiasi dengan dosis $3 \mathrm{kGy}$ pada otak-otak yang tanpa pembungkus maupun yang dibungkus tidak didapatkan pertumbuhan bakteri. Kombinasi perlakuan antara iradiasi dengan penyimpanan pada suhu rendah dapat menghambat pertumbuhan bakteri aerob setelah minggu pertama. Kontaminasi awal bakteri koli pada otak-otak yang tidak dibungkus maupun dibungkus masingmasing adalah 1,9 × $10^{5}$ dan 5,7 × $10^{5} \mathrm{cfu} / \mathrm{g}$. Iradiasi dengan dosis $3 \mathrm{kGy}$ dapat menghambat pertumbuhan bakteri koli pada semua contoh otak-otak. Kontaminasi awal bakteri Escherichia coli pada otak-otak yang tidak dibungkus maupun yang dibungkus adalah 1,2 $\times 10^{5} \mathrm{cfu} / \mathrm{g}$. Jumlah Staphylococcus spp. pada otak-otak yang tidak dibungkus dan yang dibungkus masing-masing adalah $3,3 \times 10^{5}$ dan $4,8 \times 10^{6} \mathrm{cfu} / \mathrm{g}$. Iradiasi dengan dosis 3 kGy juga dapat menghambat pertumbuhan bakteri Escherichia coli dan Staphylococcus spp. Tidak ditemukan Salmonella pada semua contoh yang diteliti.
\end{abstract}

Kata kunci: Bakteri, otak-otak, iradiasi, formalin dan boraks

\section{ABSTRACT}

THE USED OF FORMALIN, BORAX AND INITIAL BACTERIAL CONTAMINATION ON OTAK-OTAK. A research has been conducted to identify the used of formalin and borax content and also study the initial bacterial contamination on otak-otak. The wrapped and unwrapped samples were irradiated with a dose of $3 \mathrm{kGy}$ Further, the samples were stored at room temperature $\left( \pm 30^{\circ} \mathrm{C}\right)$ and low temperature $\left( \pm 4^{\circ} \mathrm{C}\right)$ up to 4 weeks. The irradiation was done at a Multipurpose Panoramic Batch Irradiatior (IRPASENA) with a dose rate of $1.149 \mathrm{kG} / \mathrm{h}$. Those samples were stored 4 weeks at 2 different temperatures and the total bacteria were oberserve every week. The measured paramater were formalin and borax content in otak-otak, the amount of total aerob bacteria, total coliforms, Escherichia coli, Staphylococcus spp., identification of Salmonella. The results showed all samples used formalin but borax was not detected. Initial contamination of total aerob bacteria for unwrapped and wrapped samples were $4.3 \times 10^{7}$ and $2.0 \times 10^{7} \mathrm{cfu} / \mathrm{g}$, respectively. Irradiation dose up to $3 \mathrm{kGy}$ showed no bacterial growth on unwrapped and wrapped samples. Combination treatment of irradiation and storage at low temperature could eliminate all aerobic bacteria at the first week. Initial contamination of coliform bacteria on unwrapped and wrapped samples were $1.9 \times 10^{5}$ and $5.7 \times 10^{5} \mathrm{cfu} / \mathrm{g}$, respectively. Initial contamination of $E$. coli on unwrapped and wrapped samples were $1.2 \times 10^{5} \mathrm{cfu} / \mathrm{g}$. The total amount of Staphylococcus spp. on unwrapped and wrapped samples were $3.3 \times 10^{5}$ and $4.8 \times 10^{6} \mathrm{cfu} / \mathrm{g}$, respectively. Irradiation at a dose of $3 \mathrm{kGy}$ could eliminate coliform bacteria, E. coli and Staphylococcus spp in all samples observed. No Salmonella was detected in all samples observed.

Keywords: Bacteria, otak-otak, irradiation, formaline and borax. 


\section{PENDAHULUAN}

Dola hidup atau gaya hidup masyarakat akhir-akir ini menghendaki segala sesuatu serba cepat dan praktis.

Salah satunya adalah di dalam penyediaan makanan yang dikonsumsi seperti otak-otak. Otak-otak dapat dikategorikan ke dalam makanan jajanan yang banyak diminati oleh kaum anak-anak hingga orang tua. Keunggulan dari makanan jajanan tersebut adalah mudah diperoleh dengan harga yang terjangkau dan dapat dimakan secara langsung maupun diolah terlebih dahulu untuk dijadikan tambahan lauk. Akan tetapi, tidak tertutup kemungkinan makanan jajanan tersebut menggunakan bahan pengawet yang dilarang dalam Peraturan Menteri Kesehatan Republik Indonesia tentang Bahan Tambahan Makanan dan disamping itu telah terkontaminasi bakteri(1).

Otak-otak merupakan salah satu makanan jajanan yang dikategorikan makanan jajanan tradisional dan terbuat dari ikan, kemudian dihaluskan dan dibumbui selanjutnya daging ikan dibungkus dan dipanggang dalam balutan daun pisang ${ }^{(2)}$. Jajanan di sekolah sebenarnya diperlukan sebagai makanan tambahan anak. Akan tetapi, banyak jajanan yang tidak memenuhi syarat keamanan pangan sehingga membahayakan kesehatan jutaan anak Sekolah Dasar. Kehadiran pedagang jajanan anak di sekolah seharusnya tidak dimatikan karena mempunyai peranan dalam menunjang perekonomian terutama bagi sektor informal(3).

Bahan Tambahan Makanan (BTM) yang belakangan ini digunakan adalah BTM yang dapat membahyakan kesehatan manusia seperti formalin. Formalin diketahui berbahaya untuk tubuh manusia karena telah diketahui sebagai zat beracun, karsinogen, mutagen yang menyebabkan perubahan sel dan jaringan tubuh, korosif dan iritatif. Uap formalin sendiri sangat berbahaya jika terhirup oleh saluran pernafasan dan iritatif jika tertelan. Disamping itu formalin juga dapat merusak persarafan tubuh manusia dan dikenal sebagai zat yang bersifat racun untuk persyarafan (neurotoksik) dan dapat mengganggu organ reproduksi seperti kerusakan testis dan ovarium, gangguan menstruasi, infertilitas sekunder. Di masyarakat formalin digunakan secara luas sebagai obat antiparasit dan sangat efektif untuk membunuh berbagai macam parasit dan bakteri yang menempel pada ikan hias. Formalin sering ditemukan pada makanan sehari-hari yang dikonsumsi seperti mi basah, ikan asin, tahu dan lain-lain(4,5). Bahan Tambahan Makanan lainnya yang juga sering digunakan adalah boraks dengan nama kimianya sodium tetraborat deksahidrat. Senyawa tersebut sedikit larut dalam air dingin dan sangat larut dalam air panas. Boraks bersifat toksik untuk semua sel dan jaringan termasuk ginjal. Dapat menimbulkan radang pada saluran pencernaan, degenerasi/pengecilan hati, pembengkakan pada otak(6).

Hasil penelitian yang dilakukan Badan Pengawas Obat dan Makanan Bandar Lampung menunjukkan bahwa dari 93 sampel produk seperti ikan segar, cumi, kerang rebus, ikan asin, cumi asin dan rebon ternyata 34 sampel atau $36,55 \%$ positif mengandung formalin ${ }^{(7)}$.

Tujuan penelitian ini untuk mempelajari ada tidaknya kandungan formalin atau borak dalam makanan jajanan anak seperti otak-otak yang dijual di sekolah dasar daerah Bekasi, Jawa Barat.

\section{METODOLOGI}

\section{Bahan}

Bahan yang digunakan dalam penelitian ini ialah makanan olahan berupa otak-otak tanpa pembungkus dan yang dibungkus daun pisang. Kemudian masing-masing contoh dibungkus dalam kantong plastik untuk diiradiasi dengan dosis $3 \mathrm{kGy} / \mathrm{jam}$ dengan laju dosis 1,149 kGy/jam, selanjutnya disimpan pada 2 macam suhu yaitu suhu kamar $\left( \pm 30^{\circ} \mathrm{C}\right)$ dan suhu $\pm 4^{\circ} \mathrm{C}$ selama 4 minggu dengan interval waktu pengamatan untuk jumlah bakteri setiap minggu.

\section{Alat}

Alat-alat yang digunakan berupa alat gelas seperti cawan petri dengan diameter $10 \mathrm{~cm}$, tabung reaksi dengan diamater $1,5 \mathrm{~cm}$, inkubator, oven, penangas air dan otoklaf. 


\section{Prosedur percobaan}

\section{Pengujian kandungan formalin dan borak}

Pengujian formalin dan borak dilakukan dengan menggunakan masing-masing reagen Formalin Main Reagent (FMR) dan reagen Borax Main Reagent (BMR) $)^{(6)}$.

\section{Penentuan jumlah total bakteri aerob, bakteri koli, dan Staphylococcus spp. pada otak-otak.}

Penentuan jumlah total bakteri aerob, bakteri koli, dan Staphylococcus spp. pada otak-otak dilakukan dengan cara menimbang contoh sebanyak $25 \mathrm{~g}$, kemudian dicampur dengan air pepton steril $(225 \mathrm{ml})$ dan selanjutnya dilakukan pengenceran bertingkat. Sebanyak 0,1 ml larutan suspensi ditanam pada media lempeng cawan petri yang berisi agar nutrien (Oxoid) untuk penentuan jumlah total bakteri aerob, sedang untuk penentuan jumlah bakteri koli, dan Staphylococcus spp. masing-masing ditanam pada media Mac Conkey dan media Baird Parker (0xoid). Pengeraman dilakukan pada suhu kamar untuk jumlah bakteri aerob, sedang untuk bakteri koli dan Staphylococcus spp. disimpan pada suhu $370^{\circ} \mathrm{C}$ selama $24-48$ jam untuk selanjutnya dihitung jumlah koloni bakteri yang tumbuh.

\section{Penentuan jumlah bakteri $E$. coli} Fardiaz $^{(8)}$.

Penentuan jumlah bakteri $E$. coli dilakukan dengan menggunakan media EMB (Oxoid) menurut metode

\section{Penentuan Salmonella}

Pemeriksaan Salmonella dilakukan dengan cara menimbang contoh sebanyak $20 \mathrm{~g}$ kemudian ditanam dalam media pengaya dan disimpan pada suhu $37^{\circ} \mathrm{C}$ selama 24 jam dan selanjutnya ditanam dalam media selektif (XLD) yang disimpan pada suhu $37^{\circ} \mathrm{C}$ selama 48 jam. Koloni yang tumbuh diidentifikasi secara mikrobiologi dan biokimia ke arah Salmonella dan dilanjutkan dengan uji serologi untuk ditentukan serotipe, seperti prosedur yang dilakukan oleh Harsojo dan June ${ }^{(9)}$.

\section{HASIL DAN PEMBAHASAN}

Makanan olahan berupa otak-otak di Jakarta dan sekitarnya mudah dijumpai dimana-mana dan disukai dari anak-anak hingga orang tua. Makanan otak-otak sering dijumpai juga dijajakan di sekolah-sekolah sebagai jajanan anak sekolah yang harganya relatif murah sehingga terjangkau dari uang saku anak sekolah. Seiring dengan kenaikan harga kebutuhan pokok karena melambungnya harga bahan bakar dunia, menyebabkan sebagian masyarakat cenderung menyederhanakan menu makanan dan ingin bahan makanan yang dijajakan atau dibeli lebih awet.

Disisi lain para pelaku usaha juga berusaha menekan biaya produksi dengan mencari bahan pengawet yang murah tanpa menghiraukan keamanan pangan. Hasil pemantauan Yayasan Lembaga Konsumen Indonesia (YLKI), belakangan ini ada penurunan kualitas sejumlah bahan pangan. Jika semula produsen hanya memperkecil produk yang dijual, maka sekarang banyak produsen mengurangi kualitas produk yang dijual dengan mengganti bahan baku produk meskipun ini akan merugikan konsumen (10).

Pengujian kandungan formalin dan borak pada contoh otak-otak dapat dilihat pada Tabel 1. Pada Tabel tersebut terlihat bahwa semua contoh otak-otak yang tidak dibungkus maupun yang dibungkus mengandung formalin. Akan tetapi, pada semua contoh otak-otak tidak mengandung boraks. Terlihat bahwa untuk mendapat bahan kimia berbahaya sangat mudah, hal ini disebabkan lemahnya pengawasan terhadap penjualan bahan kimia berbahaya yang menyebabkan pedagang makanan mudah mendapatkannya. Bahan tersebut digunakan selain untuk memperpanjang masa simpan juga untuk menekan harga jual dagangannya sehingga terjangkau oleh konsumen. Secara kasat mata, makanan yang mengandung bahan kimia berbahaya tidak akan berbeda dengan yang tidak menggunakan bahan kimia berbahaya ${ }^{(5)}$. Seperti diketahui formalin tidak boleh ada dalam makanan karena kalau terurai akan dapat menyebabkan toksisitas bagi kesehatan manusia(11,12). 
Tabel 1. Pengujian kandungan formalin dan boraks dalam beberapa sampel otak-otak

\begin{tabular}{|c|c|c|c|c|c|}
\hline \multirow{3}{*}{ Lokasi } & \multirow{3}{*}{ SD } & \multicolumn{4}{|c|}{ Jenis otak-otak } \\
\hline & & Tdk dibungkus & Dibungkus & Tdk dibungkus & Dibungkus \\
\hline & & \multicolumn{2}{|c|}{ Formalin } & \multicolumn{2}{|c|}{ Boraks } \\
\hline \multirow[t]{2}{*}{ Bojong Rawa Lumbu } & A & + & + & - & - \\
\hline & $B$ & + & + & - & - \\
\hline \multirow[t]{2}{*}{ Sepanjang Jaya } & $\mathrm{C}$ & + & + & - & - \\
\hline & D & + & + & - & - \\
\hline \multirow[t]{2}{*}{ Pengasinan } & $\mathrm{E}$ & + & + & - & - \\
\hline & $\mathrm{F}$ & + & + & - & - \\
\hline
\end{tabular}

Keterangan: $\mathrm{SD}=$ Sekolah Dasar $\mathrm{A}-\mathrm{F}=$ kode Sekolah Dasar

$$
+=\text { mengandung }-=\text { tidak mengandung }
$$

Formalin adalah larutan jenuh mengandung 37\% formaldehida, 6-13\% metanol dan sisanya adalah air. Pada umumnya formalin digunakan sebagai desinfektan, bakterisida/germisida. Formaldehida menyebabkan iritasi saluran pernafasan dan immuno toxicology, sedangkan metanol tersebut sangat beracun yang dapat menyebabkan kematian pada orang.

Adanya otak-otak yang dibungkus, tetap tidak menjadi suatu jaminan bahwa otak-otak tersebut lebih baik mutunya. Pembungkus mempunyai peranan sangat besar untuk makanan, karena bila pembungkus terkontaminasi oleh bakteri akan dapat menyebabkan terjadinya kontaminasi silang ${ }^{(13)}$.

Pengaruh iradiasi dan penyimpanan terhadap jumlah bakteri aerob dapat dilihat pada Tabel 2. Pada Tabel 2 terlihat pada otak-otak kontrol yang tidak dibungkus jumlah bakteri aerob lebih tinggi dibandingkan dengan yang dibungkus $\left(4,3 \times 10^{7}\right.$ vs $\left.2,0 \times 10^{6} \mathrm{cfu} / \mathrm{g}\right)$. Hal ini ternyata pembungkus mempunyai peranan penting dalam mencegah terjadinya kontaminasi dari udara luar. Otak-otak yang diiradiasi dengan dosis $3 \mathrm{kGy}$ pada penyimpanan 0 minggu terlihat tidak ada pertumbuhan bakteri. Pengaruh penyimpanan pada suhu rendah terlihat pada otak-otak yang dibungkus maupun yang tidak dibungkus pada penyimpanan 4 minggu terjadi penurunan jumlah bakteri aerob. Terlihat bahwa penyimpanan pada suhu rendah sangat efektif untuk menekan pertumbuhan bakteri.

Pada otak-otak yang tidak dibungkus dan disimpan pada suhu rendah dapat menekan pertumbuhan. Otak-otak yang tidak dibungkus pada penyimpanan suhu kamar selama 4 minggu didapatkan jumlah bakteri aerob sebesar $6,4 \times 10^{5} \mathrm{cfu} / \mathrm{g}$ dan setelah disimpan pada suhu $4^{\circ} \mathrm{C}$ terjadi penurunan jumlah bakteri aerob sebesar 2 desimal yaitu menjadi 2,4 $\times 10^{3} \mathrm{cfu} / \mathrm{g}$. Pada otak-otak yang dibungkus dan disimpan selama 4 minggu (suhu kamar) menunjukkan jumlah pertumbuhan bakteri sebesar $2,7 \times 10^{8} \mathrm{cfu} / \mathrm{g}$ dan pada penyimpanan suhu $4^{\circ}$ C tidak ditemukan lagi pertumbuhan bakteri aerob.

Pada perlakukan kombinasi antara iradiasi dengan dosis $3 \mathrm{kGy}$ dan penyimpanan pada suhu rendah terlihat pada otak-otak yang tidak dibungkus dengan penyimpanan 1 minggu terjadi pertumbuhan bakteri aerob dan setelah minggu ke 2 sampai akhir penyimpanan tidak lagi ditemukan pertumbuhan bakteri. Pertumbuhan pada penyimpanan 1 minggu terjadi mungkin dikarenakan bakteri yang tadinya telah mati setelah diiradiasi ternyata mengalami pingsan/ kolaps dan kemudian dapat memperbaiki kerusakan DNA yang terjadi sehingga dapat tumbuh kembali. Ternyata setelah penyimpanan minggu ke 2 dan seterusnya perbaikan DNA yang terjadi tampaknya tidak sempurna sehingga terjadi kematian., sedang pada otak-otak yang dibungkus tidak ditemukan lagi pertumbuhan bakteri. Pada dosis 3 kGy untuk otak-otak tidak dibungkus yang disimpan pada suhu kamar terlihat adanya kecenderungan kenaikan pertumbuhan bakteri dan setelah minggu ke 4 terjadi penurunan jumlah bakteri. Hal ini dikarenakan kerusakan DNA yang terjadi dapat diperbaiki kembali dan suhu kamar merupakan suhu pertumbuhan yang optimum untuk memperbaiki dan terjadi pertumbuhan. Hal inilah yang mendukung terjadinya kenaikan pertumbuhan bakteri aerob. Pada otak-otak yang dibungkus terlihat dengan dosis 3 kGy tidak terlihat pertumbuhan bakteri. Hal ini kemungkinan pembungkus berperan sebagai penghambat tersedianya oksigen, walaupun pembungkus masih dapat ditembus oleh oksigen, akan tetapi oksigen yang masuk tidak sebanyak bila dibandingkan dengan tanpa pembungkus. 
Tabel 2. Pengaruh iradiasi dan penyimpanan terhadap jumlah bakteri aerob pada 2 macam otak-otak (cfu/g).

\begin{tabular}{|c|c|c|c|c|}
\hline \multirow{2}{*}{$\begin{array}{c}\text { Dosis iradiasi } \\
(\mathrm{kGy})\end{array}$} & \multirow{2}{*}{ Jenis otak-otak } & \multirow{2}{*}{$\begin{array}{l}\text { Penyimpanan } \\
\text { (minggu) }\end{array}$} & \multicolumn{2}{|c|}{ Suhu $\left({ }^{\circ} \mathrm{C}\right)$} \\
\hline & & & $\pm 30^{\circ}$ & $\pm 4^{\circ}$ \\
\hline \multirow{10}{*}{0} & \multirow{5}{*}{ Tdk. dibungkus } & 0 & $4,3 \times 10^{7}$ & $4,3 \times 10^{7}$ \\
\hline & & 1 & $1,1 \times 10^{7}$ & $5,9 \times 10^{6}$ \\
\hline & & 2 & $9,7 \times 10^{7}$ & $4,4 \times 10^{5}$ \\
\hline & & 3 & $2,0 \times 10^{7}$ & $6,4 \times 10^{4}$ \\
\hline & & 4 & $6,4 \times 10^{5}$ & $2,4 \times 10^{3}$ \\
\hline & \multirow{5}{*}{ Dibungkus } & 0 & $2,0 \times 10^{6}$ & $2,0 \times 10^{5}$ \\
\hline & & 1 & $5,3 \times 10^{7}$ & $1,4 \times 10^{4}$ \\
\hline & & 2 & $1,2 \times 10^{7}$ & $6,0 \times 10^{2}$ \\
\hline & & 3 & $4,3 \times 10^{8}$ & $7,3 \times 10^{3}$ \\
\hline & & 4 & $2,7 \times 10^{8}$ & - \\
\hline \multirow{10}{*}{3} & \multirow{5}{*}{ Tidak dibungkus } & 0 & - & - \\
\hline & & 1 & $7,0 \times 10^{3}$ & $1,1 \times 10^{3}$ \\
\hline & & 2 & $5,2 \times 10^{4}$ & - \\
\hline & & 3 & $5,8 \times 10^{6}$ & - \\
\hline & & 4 & $2,4 \times 10^{5}$ & - \\
\hline & \multirow{5}{*}{ Dibungkus } & 0 & - & - \\
\hline & & 1 & $4,7 \times 10^{6}$ & - \\
\hline & & 2 & $2,3 \times 10^{3}$ & - \\
\hline & & 3 & - & - \\
\hline & & 4 & - & - \\
\hline
\end{tabular}

Keterangan: - = tidak tumbuh

Pada penelitian ini juga dipelajari kontaminasi bakteri koli yang terdapat pada otak-otak yang dijual di beberapa Sekolah Dasar daerah Bekasi. Kontaminasi bakteri koli sering terjadi pada makanan olahan yang disebabkan oleh penanganan secara tradisional pada saat pembuatan hingga pendistribusiannya( ${ }^{(14)}$. Adanya bakteri koli dapat digunakan sebagai parameter untuk ada tidaknya materi fekal di dalam bahan tersebut dan adanya bakteri koli di dalam makanan sangat tidak diharapkan. Disamping itu bakteri koli sering digunakan sebagai bakteri indikator sanitasi $(15,16)$. Keuntungan penggunaan bakteri koli sebagai salah satu parameter pada bahan makanan adalah bakteri tersebut lebih tahan pada proses pengolahan dan selama proses penyimpanan ${ }^{(17)}$. Oleh karena itu, penerapan teknik deteksi bakteri koli di dalam bahan sangatlah penting karena dengan demikian dapat diketahui apakah bahan tersebut masih layak digunakan atau tidak. Adanya bakteri koli dalam makanan menandakan bahwa dalam pengolahannya telah terjadi kontaminasi air yang tercemar kotoran manusia dan kemungkinan adanya mengandung bakteri patogen lainnya yang berbahaya ${ }^{(16,18)}$.

Tabel 3 menunjukkan pengaruh iradiasi dan penyimpanan terhadap jumlah bakteri koli pada 2 macam otak-otak. Pada Tabel 3 terlihat kontaminasi awal bakteri koli pada otak-otak yang tidak dibungkus dan yang dibungkus masing-masing adalah $1,9 \times 10^{5}$ dan $5,7 \times 10^{5} \mathrm{cfu} / \mathrm{g}$. Tingginya kontaminasi awal bakteri koli pada otak-otak yang dibungkus kemungkinan disebabkan air yang digunakan oleh produsen otak-otak yang dibungkus telah terkontaminasi bakteri koli yang lebih tinggi dibandingkan dengan otak-otak yang tidak dibungkus. Hal ini menunjukkan produsen kedua macam otak-otak tersebut belum memperhatikan sanitasi lingkungan sehingga sumber air yang terkontaminasi digunakan untuk pembuatan otak-otak. Disamping itu, kemungkinan produsen otak-otak belum mengetahui bahwa sumber air yang digunakan memegang peranan penting dalam produksi makanan. Penyimpanan pada suhu rendah dapat menekan pertumbuhan bakteri koli. Hal ini dikarenakan suhu optimum pertumbuhan bakteri koli adalah berkisar antara $30^{\circ}-37^{\circ} \mathrm{C}$. Pada dosis $3 \mathrm{kGy}$ dengan penyimpanan 0 minggu tidak didapatkan pertumbuhan bakteri koli untuk otak-otak yang tidak dibungkus maupun yang dibungkus. 
Tabel 3. Pengaruh iradiasi dan penyimpanan terhadap jumlah bakteri koli pada 2 macam otak-otak (cfu/g).

\begin{tabular}{|c|c|c|c|c|}
\hline \multirow{2}{*}{$\begin{array}{l}\text { Dosis iradiasi } \\
\text { (kGy) }\end{array}$} & \multirow{2}{*}{ Jenis otak-otak } & \multirow{2}{*}{$\begin{array}{c}\text { Penyimpanan } \\
\text { (minggu) }\end{array}$} & \multicolumn{2}{|c|}{ Suhu $\left({ }^{\circ} \mathrm{C}\right)$} \\
\hline & & & $\pm 30^{\circ}$ & $\pm 4^{\circ}$ \\
\hline \multirow{10}{*}{0} & \multirow{5}{*}{ Tdk. dibungkus } & 0 & $1,9 \times 10^{5}$ & $1,9 \times 10^{5}$ \\
\hline & & 1 & $7,9 \times 10^{5}$ & $4,6 \times 10^{5}$ \\
\hline & & 2 & $3,3 \times 10^{3}$ & $8,5 \times 10^{4}$ \\
\hline & & 3 & $1,4 \times 10^{4}$ & $4,4 \times 10^{4}$ \\
\hline & & 4 & $3,0 \times 10^{6}$ & $2,5 \times 10^{4}$ \\
\hline & \multirow{5}{*}{ Dibungkus } & 0 & $5,7 \times 10^{5}$ & $5,7 \times 10^{5}$ \\
\hline & & 1 & $3,6 \times 10^{5}$ & $1,6 \times 10^{3}$ \\
\hline & & 2 & - & - \\
\hline & & 3 & - & - \\
\hline & & 4 & - & - \\
\hline \multirow{10}{*}{3} & \multirow{5}{*}{ Tidak dibungkus } & 0 & - & - \\
\hline & & 1 & $2,6 \times 10^{4}$ & - \\
\hline & & 2 & $3,1 \times 10^{3}$ & - \\
\hline & & 3 & - & - \\
\hline & & 4 & - & - \\
\hline & \multirow{5}{*}{ Dibungkus } & 0 & - & - \\
\hline & & 1 & $2,7 \times 10^{3}$ & - \\
\hline & & 2 & - & - \\
\hline & & 3 & - & - \\
\hline & & 4 & - & - \\
\hline
\end{tabular}

Keterangan: - = tidak tumbuh

Hal ini kemungkinan bakteri koli mengalami kolaps dan setelah disimpan seminggu terlihat adanya pertumbuhan bakteri koli hingga minggu ke 2 pada otak-otak yang tidak dibungkus. Setelah minggu kedua tidak terlihat adanya pertumbuhan bakteri koli pada otak-otak yang tidak dibungkus sedang pada otak-otak yang dibungkus mulai dari minggu ke nol tidak terlihat adanya pertumbuhan bakteri koli. Perlakuan kombinasi antara iradiasi dengan dosis $3 \mathrm{kGy}$ dan penyimpanan pada suhu rendah dapat menekan pertumbuhan bakteri koli.

Pengaruh iradiasi dan penyimpanan terhadap jumlah bakteri $E$. coli dapat dilihat pada Tabel 4 . Bakteri $E$. coli bukan merupakan bakteri yang serius dalam konteks keamanan pangan ${ }^{(19)}$. Akan tetapi, beberapa waktu lalu E. coli di Jerman dikabarkan menyebabkan penyakit pada lebih dari 3.000 orang dan 14 orang diantaranya meninggal dunia. E. coli adalah bakteri yang hidup di usus manusia, oleh karenanya bakteri tersebut digunakan sebagai indikator sanitasi produksi pangan. Keberadaan $E$. coli di dalam makanan/bahan makanan menunjukkan adanya kontak dengan kotoran manusia. Perkembangan teknologi menunjukkan perubahan yang terjadi pada mikroorganisme, kebiasaan makan manusia, serta perubahan iklim telah memunculkan strain-strain baru sehingga didapatkan E. coli yang bersifat patogen, seperti E. coli 0157:H7. Bakteri tersebut diketahui dapat menyebabkan perdarahan dan pernah menghebohkan dunia(20). Pemeriksaan bakteri $E$. coli diperlukan karena pada makanan olahan berupa otak-otak sangat tidak diharapkan adanya bakteri $E$. coli, namun pada penelitian ini tidak dilakukan analisis lebih lanjut tentang patogenitas $E$. coli.

Pada Tabel 4 terlihat kontaminasi awal $E$. coli pada otak-otak yang tidak dibungkus maupun dibungkus jumlahnya sama yaitu 1,2 $\times 10^{5} \mathrm{cfu} / \mathrm{g}$. Terlihat bahwa air maupun sanitasi lingkungan tidak dipermasalahkan oleh produsen yang kurang mengerti pentingnya Sistem Manajemen Keamanan Mutu. Perlakuan pembungkusan dan disimpan pada suhu rendah dapat menekan pertumbuhan bakteri $E$. coli. Pada dosis $3 \mathrm{kGy}$ tidak ditemukan adanya pertumbuhan E. coli pada otak-otak yang tidak dibungkus maupun yang dibungkus. Menurut Hariyadi(21), kasus keracunan pangan dapat disebut seperti gunung es yang mungkin salah satu penyebabnya adalah dari bakteri koli. Mengingat hal ini untuk waktu yang akan datang analisis mengenai patogenitas $E$. coli sangat perlu dilakukan. 
Tabel 4. Pengaruh iradiasi dan penyimpanan terhadap jumlah bakteri E. coli pada 2 macam otak-otak (cfu/g).

\begin{tabular}{|c|c|c|c|c|}
\hline \multirow{2}{*}{$\begin{array}{c}\text { Dosis iradiasi } \\
\text { (kGy) }\end{array}$} & \multirow{2}{*}{ Jenis otak-otak } & \multirow{2}{*}{$\begin{array}{c}\text { Penyimpanan } \\
\text { (minggu) }\end{array}$} & \multicolumn{2}{|c|}{ Suhu $\left({ }^{\circ} \mathrm{C}\right)$} \\
\hline & & & $\pm 30^{\circ}$ & $\pm 4^{\circ}$ \\
\hline \multirow{10}{*}{0} & \multirow{5}{*}{ Tidak dibungkus } & 0 & $1,2 \times 10^{5}$ & $1,2 \times 10^{5}$ \\
\hline & & 1 & $3,0 \times 10^{4}$ & $3,8 \times 10^{4}$ \\
\hline & & 2 & $2,3 \times 10^{4}$ & $1,8 \times 10^{4}$ \\
\hline & & 3 & $2,0 \times 10^{3}$ & $6,5 \times 10^{3}$ \\
\hline & & 4 & $3,0 \times 10^{2}$ & $7,5 \times 10^{2}$ \\
\hline & \multirow{5}{*}{ Dibungkus } & 0 & $1,2 \times 10^{5}$ & $1,2 \times 10^{5}$ \\
\hline & & 1 & $5,5 \times 10^{3}$ & - \\
\hline & & 2 & - & - \\
\hline & & 3 & - & - \\
\hline & & 4 & - & - \\
\hline \multirow{10}{*}{3} & \multirow{5}{*}{ Tidak dibungkus } & 0 & - & - \\
\hline & & 1 & - & - \\
\hline & & 2 & - & - \\
\hline & & 3 & - & - \\
\hline & & 4 & - & - \\
\hline & \multirow{5}{*}{ Dibungkus } & 0 & - & - \\
\hline & & 1 & - & - \\
\hline & & 2 & - & - \\
\hline & & 3 & - & - \\
\hline & & 4 & - & - \\
\hline
\end{tabular}

Keterangan: - = tidak tumbuh

Pada semua contoh otak-otak yang diteliti tidak ditemukan adanya bakteri Salmonella. Walaupun demikian tidak berarti bahwa makanan olahan berupa otak-otak tersebut aman untuk dikonsumsi karena hasil kontaminasi awal diketahui pada semua contoh otak-otak yang dijual di Sekolah Dasar telah terkontaminasi $E$. coli.

Pada penelitian ini juga dilakukan pengamatan terhadap Staphylococcus spp. Bakteri tersebut walaupun tidak berbahaya seperti Salmonella, akan tetapi perlu juga mendapat perhatian karena dapat juga menimbulkan keracunan. Keracunan oleh Staphylococcus spp merupakan gejala intoksikasi yang paling banyak dilaporkan di Amerika Serikat. Setiap tahunnya 20 sampai $50 \%$ dari seluruh keracunan disebabkan oleh makanan ${ }^{(15)}$. Staphylococcus menghasilkan toksin yang dapat menyebabkan gastroenteritis atau inflamasi pada saluran usus.

Tabel 5 menunjukkan perlakuan kombinasi antara iradiasi dan penyimpanan terhadap bakteri Staphylococcus spp. Pada Tabel 4 terlihat kontaminasi awal bakteri Staphylococcus spp pada otak-otak yang tidak dibungkus maupun dibungkus masing- masing adalah $3,3 \times 10^{5}$ dan 4,8 $\times 10^{6} \mathrm{cfu} / \mathrm{g}$. Tingginya kontaminasi bakteri Staphylococus spp pada otak-otak yang dibungkus disebabkan produsen tidak memperhatikan sanitasi lingkungan dibandingkan dengan produsen otak-otak yang tidak dibungkus. Otak-otak yang tidak dibungkus produsennya berlainan dengan otak-otak yang dibungkus. Pada dosis $3 \mathrm{kGy}$ tidak ditemukan adanya pertumbuhan bakteri Staphylococcus spp pada contoh otak-otak yang tidak dibungkus maupun yang dibungkus.

Kejadian Luar Biasa (KLB) yang disebabkan oleh Salmonella maupun Staphylococcus spp. di Indonesia belum banyak dilaporkan dan dapat disebut fenomena gunung es karena pangan dikonsumsi setidaknya tiga kali sehari(22). Persentase jumlah yang dilaporkan masih terlalu kecil bila dibandingkan dengan wabah yang sebenarnya terjadi(23). Menurut Jenie(24), letusan penyakit asal pangan yang terjadi di negara berkembang menyebabkan kematian 2,2 juta anak oleh penyakit diare. Penyebab diare adalah bakteri patogen berasal dari pangan maupun dari air. Salmonella merupakan salah satu bakteri yang disebarluaskan melalui makanan dan paling patogen dibandingkan dengan bakteri patogen lainnya. 
Tabel 5. Pengaruh iradiasi dan penyimpanan terhadap jumlah bakteri Staphylococcus spp. pada 2 macam otakotak $(c f u / g)$.

\begin{tabular}{|c|c|c|c|c|}
\hline \multirow{2}{*}{$\begin{array}{l}\text { Dosis iradiasi } \\
\text { (kGy) }\end{array}$} & \multirow{2}{*}{ Jenis otak-otak } & \multirow{2}{*}{$\begin{array}{l}\text { Penyimpanan } \\
\text { (minggu) }\end{array}$} & \multicolumn{2}{|c|}{ Suhu ( $\left.{ }^{\circ} \mathrm{C}\right)$} \\
\hline & & & $\pm 30^{\circ}$ & \pm 40 \\
\hline \multirow{10}{*}{0} & \multirow{5}{*}{ Tidak dibungkus } & 0 & $3,3 \times 10^{5}$ & $3,3 \times 10^{5}$ \\
\hline & & 1 & $1,0 \times 10^{6}$ & $2,7 \times 10^{5}$ \\
\hline & & 2 & $1,0 \times 10^{5}$ & $1,3 \times 10^{6}$ \\
\hline & & 3 & - & - \\
\hline & & 4 & - & - \\
\hline & \multirow{5}{*}{ Dibungkus } & 0 & $4,8 \times 10^{6}$ & $4,8 \times 10^{6}$ \\
\hline & & 1 & $4,8 \times 10^{7}$ & $7,0 \times 10^{5}$ \\
\hline & & 2 & - & - \\
\hline & & 3 & - & - \\
\hline & & 4 & - & - \\
\hline \multirow{10}{*}{3} & \multirow{5}{*}{ Tidak dibungkus } & 0 & - & - \\
\hline & & 1 & - & - \\
\hline & & 2 & - & - \\
\hline & & 3 & - & - \\
\hline & & 4 & - & - \\
\hline & \multirow{5}{*}{ Dibungkus } & 0 & - & - \\
\hline & & 1 & - & - \\
\hline & & 2 & - & - \\
\hline & & 3 & - & - \\
\hline & & 4 & - & - \\
\hline
\end{tabular}

Keterangan: - = tidak tumbuh

Pada penelitian ini tidak terlihat jelas korelasi antara penggunaan formalin dengan jumlah bakteri yang terkandung di dalam sampel. Hal ini disebabkan produsen tidak mempunyai takaran yang pasti saat pembuatan otak-otak, untuk produsen yang penting otak-otak yang tidak habis terjual hari ini masih dapat disimpan sampai besok dan otak-otak tesebut agak kenyal (tidak keras).

\section{KESIMPULAN}

Penggunaan formalin ditemukan pada semua contoh otak-otak, tetapi tidak ditemukan adanya penggunaan borax. Kombinasi perlakuan antara iradiasi dan suhu penyimpanan memegang peranan penting dalam pertumbuhan bakteri. Dosis $3 \mathrm{kGy}$ mampu menekan pertumbuhan bakteri aerob, koli, E. coli dan Staphylococcus spp. Pada semua sampel yang diteliti tidak ditemukan adanya Salmonella..

\section{DAFTAR PUSTAKA}

1. ANONIM, Badan Pengawas Obat dan Makanan, Formalin, Direktorat Pengawasan Produk dan Bahan Berbahaya Deputi Bidang Pengawasan Pangan dan Bahan Berbahaya, Jakarta (2003).

2. Http:lid.wikipedia.org/wiki/otak-otak, diakses tanggal 20 Agustus (2009).

3. ANONIM, Waspadai jajanan anak di sekolah, Harian KOMPAS, 11 November (2005) 13.

4. ANONIM, Soal formalin Sangat berbahaya bagi kesehatan manusia. Harian Kompas, 3 Januari (2006) 13.

5. ANONIM, Ditemukan makanan mengandung formalin. Harian Kompas, 21 Desember (2005) 24

6. C. Mahdi, Mengenal bahaya formalin, boraks, dan zat warna berhaya, (2008), belum diterbitkan.

7. Anonim, Makanan ilegal, Pengawasan Bahan Kimia Berbahaya Lemah, Harian Kompas, 12 Agustus (2011) 13.

8. S. FARDIAZ, Penuntun praktek mikrobiologi pangan IPB. Bogor. (1989).

9. HARSOJO dan J. MELLAWATI, Indo. J. Chem. (2) (2009) 226-230.

10. ANONIM, Negara belum mampu lindungi konsumen. Harian KOMPAS, 10 November (2005) 13. 
11. ANONIM, Awasi jajanan disekolah, Harian KOMPAS, 23 Desember (2005)13.

12. ANONIM, Foodreview Indonesia IV (5) (2009) 26.

13. SRI POERNOMO, Standar higiene dan keamanan pangan, Bahan Penataran Manajemen Usaha Jasa Boga. IPB-Bogor (1995).

14. P. LOAHARANU, Irradiation foods, $5^{\text {th }}$ ed. American Council on Science and health. (2003).

15. I. SUPARDI dan SUKAMTO, Mikrobiologi Dalam Pengolahan dan Keamanan Pangan. Penerbit Alumni; Bandung (1999).

16. U. SURIAWIRIA, Mikrobiologi air dan dasar dasar pengolahan buangan secara biologis. Penerbit Alumni ITB; Bandung (2003)

17. HARSOJO, SAINTEKS XIV (1) (2006)12-19

18. HARSOJO, dan L.S. ANDINI, SAINTEKS XI (1) (2003) 30-38

19. R.D. HARIYADI, Bakteri penyebab diare mematikan, Harian KOMPAS 14 Juni (2011) 13

20. F.G. WINARNO, Apakah produk pangan di Amerika Serikat "Paling aman"?. Harian KOMPAS, 11 Maret (2003) 30.

21. R.D. HARIYADI, Keracunan pangan tidak hanya sebabkan diare. Harian Kompas 15 Desember (2002) 32.

22. R.A. SPARRINGA, Investigasi Kejadian Luar Biasa (KLB) Keracunan Pangan di Indonesia: Masalah dan saran Pemecahannya. Dibawakan pada Pertemuan IImiah Tahunan Perhimpunan Mikrobiologi Indonesia (2004)

23. W.P. RAHAYU, Kebijakan keamanan pangan. Dibawakan pada Seminar dan diskusi IImiah: Mutu \& Keamanan Pangan, IPB, Bogor 11 Juni (2004).

24. B.S.L. JENIE, Keamanan pangan, dibawakan pada Seminar dan Diskusi Ilmiah: Mutu \& Keamanan Pangan, IPB, Bogor 11 Juni (2004). 